\title{
種々の抗血小板膜抗体の血小板機能におよぼす影響
}

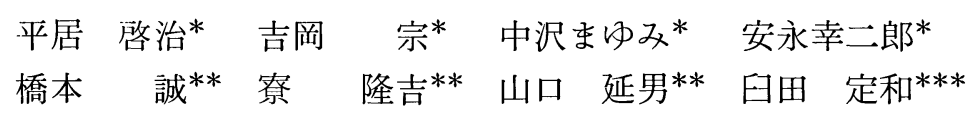

\section{Effects of various types of anti-human platelet membrane antibody on platelet function}

\author{
Keiji HIRAI*, Muneto YOSHIOKA*, Mayumi NAKAZAWA*, \\ Kojiro YASUNAGA*, Makoto HASHIMOTO**, Ryukichi RYO**, \\ Nobuo YAMAGUCHI** and Sadayuki USUDA***
}
Key words: platelet membrane, glycoprotein IIb/IIIa, platelet aggregation, crossed immunoelectrophoresis, immunoprecipitation, immunoblotting

Antibodies I and II (heterologous anti-human platelet membrane antisera) were produced in rabbit against human platelet membrane dissolved in $10 \mathrm{mM}$ Tris/ $\mathrm{HCl}$ buffer, $\mathrm{pH} 7.4$, containing $1 \%$ Triton $\mathrm{X}-100,0.25 \mathrm{M}$ sucrose, $2 \mathrm{mM}$ $\mathrm{CaCl}_{2}$, and in $38 \mathrm{mM}$ Tris/ $\mathrm{HCl}$ buffer, $\mathrm{pH} 8.6$, containing $1 \%$ Triton $\mathrm{X}-100,0.1$ $\mathrm{M}$ glycine, $5 \mathrm{mM}$ EDTA, respectively. Antibody III (mouse monoclonal antibody) was raised against crude human platelet membrane of normal platelets. By crossed immunoelectrophoresis (CIE), it was shown that antibody I could bind to a single protein. Since the immunoprecipitate on CIE was not detectable by using platelets from a Glanzmann's thrombasthenic patient, antibody I was considered to be specific antibody against GP IIb/IIIa complex. Avidin biotin complex system $(\mathrm{ABC})$-immunoblot showed the strong binding of antibody II to electrophoretically separated GP IIb and GP IIIa. ABC-immunoblot revealed no binding of antibody III to platelet proteins after SDS-PAGE, but two immunoprecipitates were obtained with an apparent molecular weight of $130 \mathrm{~K}$ and $110 \mathrm{~K}$

* 関西医科大学第一内科 [ $\overline{\mathbf{T}} 570$ 大阪府守口市文園町1], The First Department of Internal Medicine, Kansai Medical University, Osaka, Japan.

** 神戸大学医学部附属病院輸血部, Blood Transfusion Service, Kobe University Hospital, Hyogo, Japan.

*** 特殊免疫研究所, Institute of Immunology, Tochigi, Japan. 
under reduced conditions by double antibody immunoprecipitate, thus indicating that antibody III was a monoclonal antibody against GP IIb/IIIa complex. Fluorescence flow cytometric analysis showed that the activity of antibody I to sensitize human platelets was less than that of antibody II. In contrast, antibody I was more potent in inhibiting $\mathrm{ADP}$-and collagen-induced platelet aggregation than antibody II. Antibody III inhibited ADP-and collagen-induced aggregation in a dose dependent manner. The addition of $6.3 \mu \mathrm{g} / \mathrm{m} l$ of antibody III to platelets sensitized $68 \%$ of platelets, and caused complete inhibition of ADP-induced aggregation, while its addition of $3.1 \mu \mathrm{g} / \mathrm{m} l$ sensitized $50 \%$ of platelets, and caused complete inhibition of collagen-induced aggregation. The results give further support to the proposal that platelet GP IIb/IIIa complex, not dissociated GP IIb and GP IIIa, plays an important role in platelet aggregation.

\section{緒言}

血小板膜には凝集能や粘着能などの機能発現 に重要な働きをする glycoprotein (GP) が存在 している. その中でも GP IIb/IIIa は complex を形成してはじめて凝集発現に中心的役割を果 たすことが推定されている興味ある GP であ る ${ }^{1)}$. そこで血小板膜 GP IIb/IIIa に比較的特 異性のある各種の抗体を作製して, GP IIb/IIIa の凝集の際に果たす役割を検討したので報告す る.

\section{I. 万 法}

抗体作製：正常人よりチトラート採血（3.8 \%クエン酸ナトリウム 1 容：血液 9 容）した血 液を $300 \mathrm{~g}$ で 8 分間遠心して多血小板血漿 (P $\mathrm{RP})$ を得て，血小板を $15 \%$ ACD 加 PBS ( $\mathrm{pH}$ 7.4）で洗浄した. その血小板を Barber と Jamieson の方法 ${ }^{2)}$ 飞従って血小板膜分画を得て, それを $1 \%$ Triton X-100, $0.25 \mathrm{mM}$ sucrose, $2 \mathrm{mM} \mathrm{CaCl}_{2}$ を含有する $10 \mathrm{mM}$ Tris $/ \mathrm{HCl}, \mathrm{pH}$ 7.4 の緩衝液（ I 群）と $1 \%$ Triton X-100, $0.1 \mathrm{M}$ glycine, $5 \mathrm{mM}$ EDTA を含有する 38 $\mathrm{mM}$ Tris $/ \mathrm{HCl} \mathrm{pH} 8.6$ の緩衝液 (II群) で溶 解し, 家兔を免疫して抗血小板膜抗体 ${ }^{3)}$ を, ま た 0i らの方法 ${ }^{4)}$ 準じて抗血小板膜モノクロー ナル抗体を得た（III群）. 家鬼由来の抗血清は $56^{\circ} \mathrm{C} ， 30$ 分間非働化して，モノクローナル抗体 は生食で $5 \mathrm{mg} / \mathrm{ml}$ の濃度に調整して以下の実 験に供した.
抗体の性状 : 二次元交差免疫 電気 泳 動 CIE 以下 (C) 法と略す) は Hagen らの方法 ${ }^{5}$ 飞従 い，抗血清を $10 \%$ になるよう agarose に混じて 招こない，中間 gel は使用しなかった．抗原は 上記の方法により得られた血小板膜，あるいは Glanzmann の血小板無力症 ( I 型) より得た血 小板を $15 \%$ ACD 加 PBS (pH 7.4) 飞て洗浄 し, その血小板を $1 \%$ Triton X-100, $100 \mathrm{mM}$ glycine を含む $38 \mathrm{mM}$ Tris $/ \mathrm{HCl}, \mathrm{pH} 8.7$ の 緩衝液に溶解して検索した. 蛋白量は Bio Rad 社の protein assay kit I を用いて測定した。

Avidin biotin peroxidase complex (ABC) -immunoblotting (W) 法は, 正常人より得た 血小板を $5 \mathrm{mM}$ EDTA を含む PBS ( $\mathrm{pH} 7.4$ ) で洗浄し，その血小板 $(100 \mu \mathrm{g})$ を Laemmli の方法 ${ }^{6}$ に従って $5 \%$ 2-mercaptoethanol を含 む試料用緩衝液で溶解し $100^{\circ} \mathrm{C} 5$ 分間者沸後, $5.5 \%$ SDS polyacrylamide gel (SDS-PAGE) で電気泳動後, Trans Blot Electrophoretic Blotting Apparatus (Bio Rad 社) を用いて nitrocellulose に転写? ${ }^{2}$ し，その後抗血清を $0.05 \%$ Tween 20 を含んだ PBS (TPBS) で希釈して nitrocellulose 上で抗原抗体反応を招こさせて, 結合した IgG Vectastain ABC kit (Vector 社) で同定した. 分子量は HMW maker (Bio $\operatorname{Rad}$ 社）を用いて決定した.

Immunoprecipitate (I) 法は, Phillips らの方 法8) に従い lactoperoxidase (Sigma 社) を用い て $1 \mathrm{mCi}{ }^{125}$ I (Amersham 社) で $1 \times 10^{9}$ 個の正 常人より得た血小板を標識した後, McGregor 


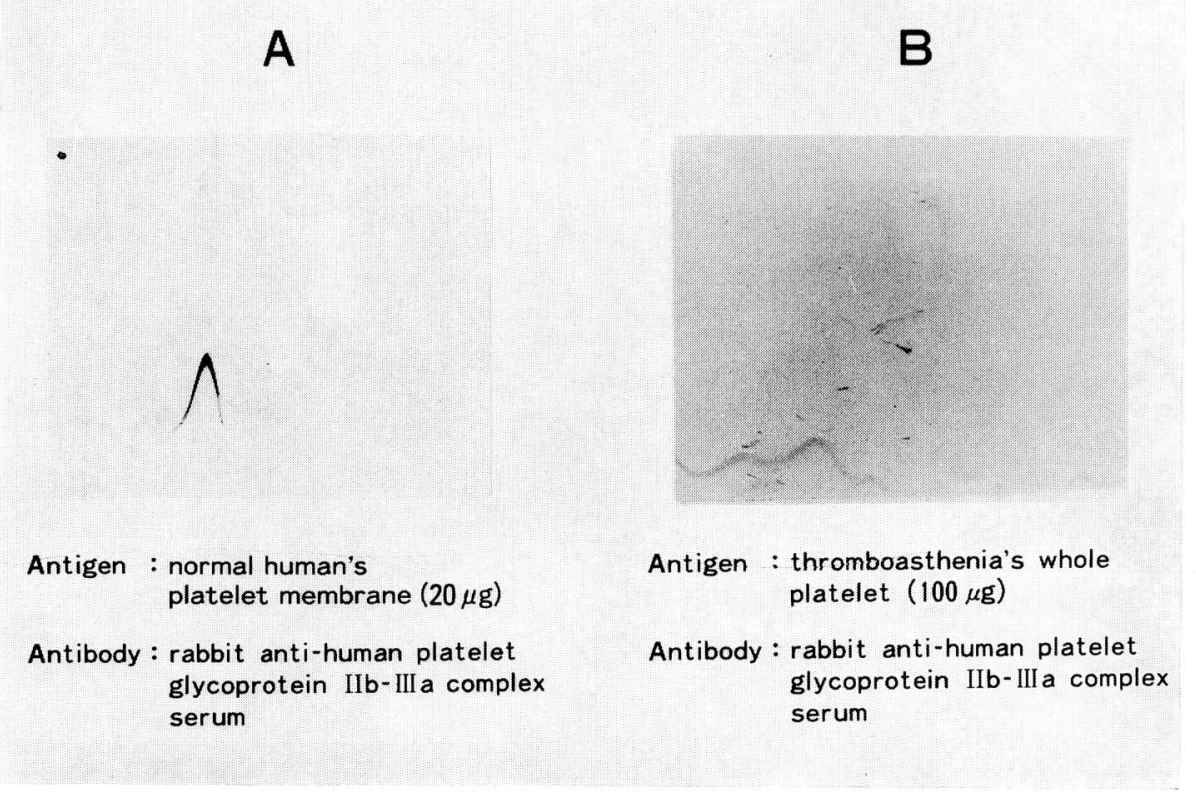

Fig. 1 Analysis of antigen against antibody I

Platelet membrane $(20 \mu l)$ from normal subjects and washed platelets $(100 \mu \mathrm{g})$ from Glanzmann's thrombasthenia solublized in lysis buffer $(38 \mathrm{mM}$ Tris $/ \mathrm{HCl}$ buffer, $\mathrm{pH} 8.7$, cntaining $1 \%$ Triton $\mathrm{X}-100$ and $100 \mathrm{mM}$ glycine) were electrophoresed (left to right) in first dimension agarose gels containing $1 \%$ Triton $\mathrm{X}-100$, and then in the second dimension against 10\% antibody I in the upper gel. The gels were washed, dried and the precipitates were stained by Coomassie brilliant blue.

A shows the immunoprecipitates of normal platelet membrane.

B shows the immunoprecipitates of Glanzmann's thrombasthenic platelets.

らの方法 ${ }^{9)}$ に準じて $2 \times 10^{8}$ 個の ${ }^{125}$ I-標識血小 板を $0.15 \mathrm{M} \mathrm{NaCl}, 1 \%$ Triton X-100, $0.1 \%$ SDS を含む $2 \mathrm{mM}$ Tris $/ \mathrm{HCl}, \mathrm{pH} 7.2$ の溶解 液で溶解し，各種濃度の抗体を反応させて，家 鬼由来抗マウス Ig (Cappel 社) あるいはヤギ 由来抗家鬼 Ig (Cappel 社) を加えて，その抗 原抗体複合体を $10 \%$ staphylococcus aureus Cowan I (科薬) で沈殿させて, Laemmli の $5 \%$ mercaptoethanol を含む試料用緩衝液で溶解 し, $5.5 \%$ SDS-PAGE で電気泳動後, Kodak $\mathrm{X}$ Omat S film (Kodak 社) 用いて autoradiography を行ない検索した.

抗体の力価は Borne ${ }^{10)} の$ platelet suspension immunofluorecence test (PSIFT) で検討し, 螢光強度を flow cytometry (Ortho Spectrum III $)^{11)}$ で測定した. non-immune のマウス腹水
の反応に特いて䖝光を発する細胞が $1 \%$ 以下に なるよう条件設定し，血小板上の䖝光強度を測 定した。

血小板凝集能 : Born の比濁法 ${ }^{12)}$ 飞従い $\mathrm{He}$ matracer (二光バイオサイエンス社) を用いて 測定した. 正常人より $3.8 \%$ クェン酸ナトリウ ム $1 / 10$ 容で採血して $300 \mathrm{~g}, 8$ 分間遠心して得 られた PRP $190 \mu l\left(4 \times 10^{6}\right.$ 血小板 $\left./ \mu l\right)$ と 10 $\mu l$ の各種濃度の抗体と 60 分間, $37^{\circ} \mathrm{C}$ で餒置し た後, $4 \mu \mathrm{M}$ ADP (Sigma 社) と $1 \mu \mathrm{g} / \mathrm{m} l$ 市 るいは $2 \mu \mathrm{g} / \mathrm{m} l$ collagen (Horm 社) を加えて 凝集能を観察し，最大凝集率を測定した，凝集 率は，そのとき用いた PRP の光の透過度を 0 \%とし，乏血小板血漿のそれを $100 \%$ とした。 


\section{$\leftarrow 130 \mathrm{~K}$
$\leftarrow 110 \mathrm{~K}$}

$\times 256$ $\times 512$ $\times 1024$

Fig. 2 Western blot showing the interaction between antibody II and electrophoretically separated GP IIb and GP IIIa of normal human platelets.

Samples $(100 \mu \mathrm{g})$ of reduced SDS soluble platelet proteins were separated by 5. 5\% acrylamide Laemmli SDS/acrylamide gel (SDS PAGE) and electrophoretically transfered to nitrocellulose membrane. Individual strips were incubated with antiserum diluted at various concentrations with PBS containing $0.05 \%$ Tween20 (TPBS). Detection of $\operatorname{IgG}$ was performed using avidin biotin peroxidase complex method. Lane 1, 2, 3 and 4 show immunoblot with antibody II diluted as indicated.

\section{II. 成 樍}

I 群の抗体は W 法や I 法では diffuse な抗原 部位を認識したが，C法では正常の血小板膜を 抗原とすると単一な沈降線を形成し，血小板無 力症患者から得られた血小板を抗原とすると消 失するので， GP IIb/IIIa complex に特異性が ある抗体と考克られた（図1）．川群の抗体は I 法では血小板膜飞 diffuse に反応して, 特定 の抗原部位を同定できなかったが, $\mathrm{W}$ 法で還 元した血小板の $130 \mathrm{~K}$ と $110 \mathrm{~K}$ の部位に結合 したので，解離したGP IIb と GP IIIa に対 する比較的特異性の西る抗体之考兄られた（図 2). C 法では, 検索する血小板膜をEDTA で 処理すると I 群の抗体では全く沈降線を形成し

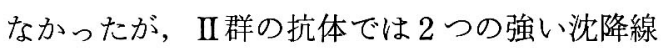
を形成したので，II群の抗体が解離した GP IIb と GP IIIa 飞比較的特異性があることが確 認された． III群の抗体はW法では結合部位は同
定できなかったが，I法で GP IIb と GP IIIa に一致した分子量の抗原を沈殿させたので, GP IIb/IIIa complex に対するモノクローナル 抗体と考兄られた（図3). これらの抗体の力 価と凝集阻害の関係を 3 名の正常人から得ら机 た血小板を用いて検討した．図 $\mathbf{4}$ はとの代表的 な例を示している. I 群の抗体はII 群の抗体上 り抗体力価が低いにもかかわらず，凝集の阻害 の程度が強く, また, 両抗体とも ADP ょり collagen 凝集をより強く抑制した. 一方, III群 の抗体は感作された血小板が $68 \%$ オ ADP 凝集 を，50\%で collagen 凝集を完全に抑制した. な抢，他の 2 名も agonist に上る最大㠜集率や 抗体に対する反応性に違いが認められたが，抗 体の力価と凝集阻害の関係は同じであった。

\section{III. 考 案}

各種の血小板抗体を用いて血小板機能発現の 機序の解明がおこなわれている. そこで血小板 


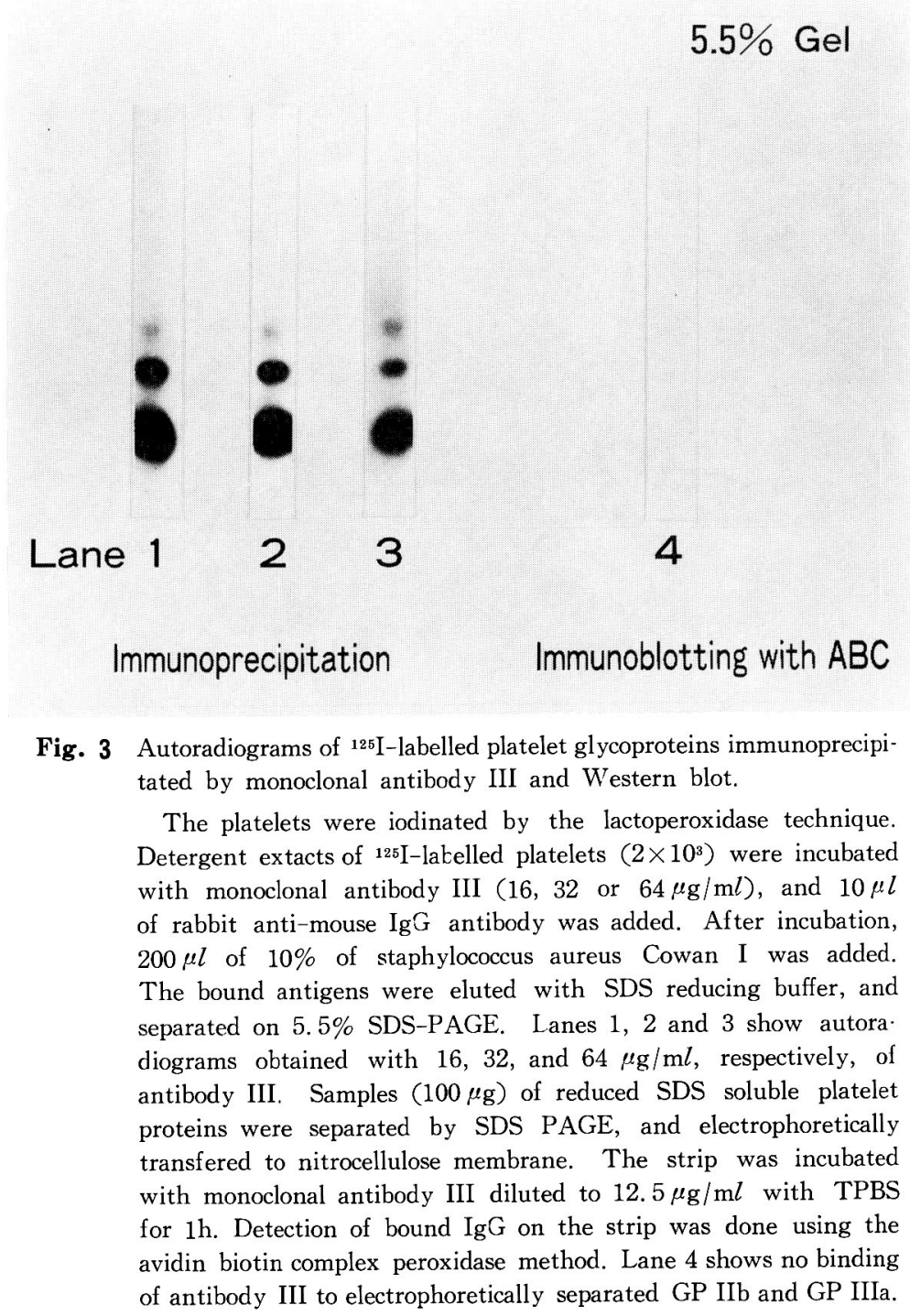

膜とくにに GP IIb/IIIa 対する三種の抗体を作 製して，これらの抗体の凝集能に叔よ汸す影響 を観察した，血小板を EDTA 非存在下あるい は存在下で Triton X-100 で可溶化すると Nurden ら ${ }^{13)}$ の報告したように ETDA 存在下で は血小板膜の GP IIb/IIIa complex は消失す る. 血小板膜を EDTA 存在下と非存在下で処 理して家鬼を免疫すると，興味あることに性状 の異なった抗血清が得られた.いずれの抗血清 も血小板膜といら crude な抗原を用いたので I 法では血小板膜に diffuse に反応することが認 められたが, CIE の成績から EDTA 非存在下
の抗血清は GP IIb/IIIa complex に比較的特異 性のある抗体であり, 一力, EDTA 存在下の 抗血清は ABC-immunoblotting 法で解離した 血小板膜 GP IIb と GP IIIa を比較的強く認識 することが明らかとなった。これは, EDTA が Ca 依存性の血小板膜 GP IIb/IIIa complex を解離したために後者の抗血清が, 解離した GP IIb と GP IIIa そ特異性を有するようにな ったためと考えられる. そこでこの二つの抗体 を用いて ADP と collagen 凝集の阻害の態度 を観察すると GP IIb/IIIa complex に比較的特 異性のある膜抗体は, 解離した GP IIb と GP 


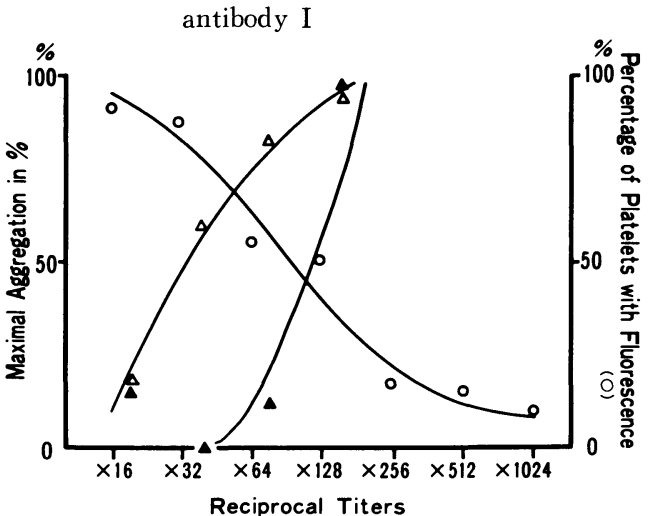

of antibody antibody II

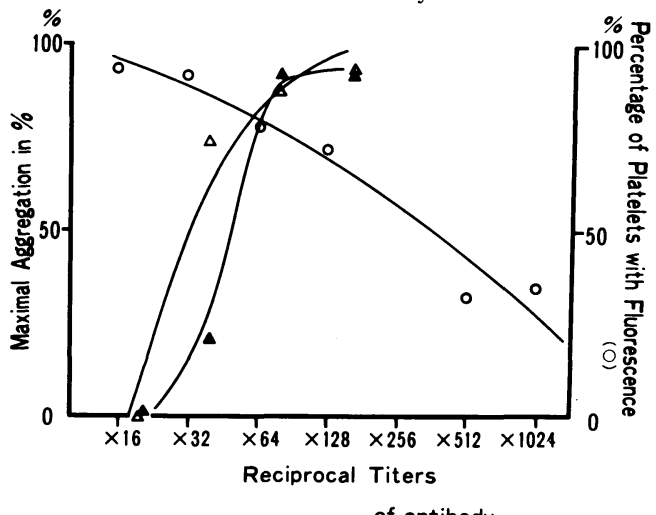

of antibody

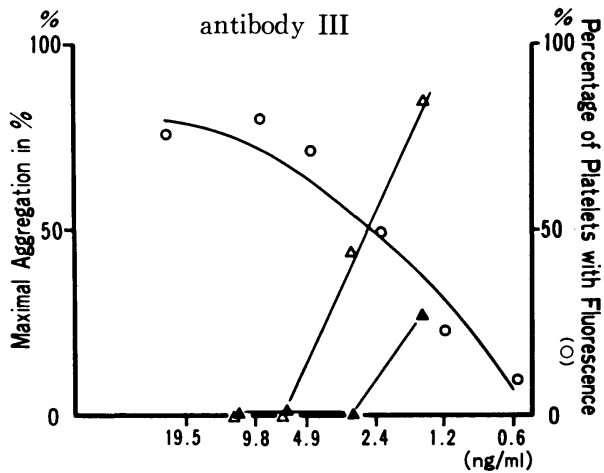

$\frac{A \mid B}{C}$

Fig. 4 Relationship between inhibition of platelet aggregation in the presence of antibody and the numbers of antibody-sensitized platelets.

Rabbit anti-human platalet membrane antibodies (antibody I and antibody II) and IgG of mouse anti-human platelet GP IIb/IIIa complex monoclonal antibody (antibody III) were incubated with normal human PRP prior to the addition of ADP and collagen (4 $\mu \mathrm{M} \mathrm{ADP}$ and $1.0 \mu \mathrm{g} / \mathrm{m} l$ collgen were used for platelet aggregation in the presence of antibody I and II. $4 \mu \mathrm{M} \mathrm{ADP}$ and $2 \mu \mathrm{g} / \mathrm{m} l$ collagen were used for platelet aggregation in the presence of antibody III). The maximal aggregetion is expressed as a percentage of aggregation $5 \mathrm{~min}$ after the addition of $\operatorname{ADP}(\Delta)$ and collagen $(\Delta)$. The formalin-fixed platelets were incubated with varying dilutions of antibodies, then incubated with the fluorescein labelled second antibody. The fluorescence histograms were analyzed on flow cytomtry, and the percentage of platelets with positive fluorescence is indicated (O).

$\mathrm{A}, \mathrm{B}$ and $\mathrm{C}$ show the effects of antibodies I, II, III, respectively.

IIIa に対する膜抗体に比較して, ADP と collagen 凝集をより強く抑制した.これは GP IIb/ IIIa complex を形成してはじめて凝集能発現に 中心的な役割を果たすという従来の見解年を支 持する成績と考えられた。 また，自家製の GP IIb/IIIa complex モノクローナル抗体も $6.3 \mu \mathrm{g} /$ $\mathrm{m} l$ で ADP 凝集を, $3.1 \mu \mathrm{g} / \mathrm{m} l$ で collagen 凝集 を完全に阻害し，GP IIb/IIIa complex が凝集
をつかさどる膜 GP であることが確認された 興味あることにこの際，血小板への抗体の結合 を flow cytometry で検討すると68\%と50\%で あり，GP IIb/IIIa complex が抗体によって完 全に扮扮われていなくても，凝集の発現が阻止 された. 血小板膜 GP IIb/IIIa complex の数と 凝集能の強さの関係を検討すると，凝集能発現 の際の GP IIb/IIIa complex の役割が一層明ら 
かになると考兄られた. 今回用いた種々の抗体 はいずれも ADP より collagen 凝集を強く阻 害した。これは各抗体が， collagen によって血 小板から放出される ADP による凝集を阻止す るためか, receptor を介する阻害かについては 今後の課題である.

\section{文献}

1) Clemetson, K.J.: Glycoprotein of the platelet plasma membrane. (George, J.N., Nurden, A. I., and Phllips, D.R.: Platelet Membrane Glycoproteins), Plenum Press, New York, 1985, pp. 51 86.

2) Barbet, A. J. and Jamieson, G. A.: Isolation and characterization of plasma membrane from human blood platelets. J. Biol. Chem., 245; 6357 6365, 1970.

3）中沢玉ゆ久, 寮 隆吉: 抗血小板膜抗体の作 製一とくに glycoprotein IIb と IIIa そついて一. 投稿中

4) Oi, V.T. and Herzenberg, L. A.: Immunogloblin producing hybrid cell lines. (Mishell, B.B. and Shiigi, S.M.: Selected Methods in Cellular Immunology.), Fremann Press, San Francisco, 1980, pp. 351 572.

5) Hagen, I., Bjerrum, O.J. and Solum, N.O.: Characterization of human platelet proteins solubilized with Triton X-100 and examined by crossed immunoelectrophoresis. Referance patterns of extracts from whole platelets and isolated membranes. Eur. J. Biochem., 99; 9 22, 1979 .

6) Laemmli, V.K.: Cleavage of structural proteins during the assembly of the head of bacteriophage T. Nature, 227; 680 685, 1970.

7) Devine, D.V. and Rosse, W.F.: Identification of platelet proteins that bind alloantibodies and autoantibodies. Blood, 64; 1240 1245, 1984.

8) Phillips, D.R. and Agin, P.P.: Platelet plasma membrane glycoproteins. Evidence for the presence of nonequivalent disulfide bounds using nonreduced-reduced two-dimentional gel electrophoresis. J. Biol. Chem., 252; 2121 2126, 1977.

9) McGregor, J.L., Brochier, J., Wild, F., Follea, G., Trzeciak, M.C., James, E., Dechavanne, M., McGregor, L. and Clemetson, K., J.: Monoclonal antibodies against platelet membrane glycoproteins. Eur. J. Biochem., 131; 427 436, 1983.

10) von dem Borne, A.E.G.K., Verheugt, F.W. A., Oosterhof, F. von, Riesz, E., Brutel de la Riviere, A. and Engelfriet, C.P.: A simple immunofluorescence test for the detection of platelet antibodies. Br. J. Haematol., 39; 195 $\sim 207,1978$.

11）西郷勝康，中谷洋子，山口延男，橋本 誠，寮 隆吉：抗血小板抗体の in vivoでの巨核球への 結合．血液と脈管，16；187～190，1985.

12) Born, G.V.R.: Aggregation of blood platelet by adenosine diphosphate and its reversal. Nature, 194; 927 929, 1962.

13) Rosa, J.-P., Kieffer, N., Didry, D., Pidard D., Kunicki, T. and Nurden, A. T.: The human platelet membrane glycoprote!n complex GP IIb-IIIa express antigen sites not exposed on the dissociated glycoproteins. Blood, 64; 1246 1253, 1984.

14) Nachman, R.L. and Leung, L.L.: Complex formation of platelet membrane glycoproteins IIb and IIIa with fibrinogen. J. Clin. Invest., 69; 263 299, 1982 . 